\title{
Seasonal Changes in the Distribution and Abundance of Marine Cladocerans of the Northwest Alboran Sea (Western Mediterranean), Spain.
}

\author{
Christiane Sampaio de Souza ${ }^{1 *}$, Paulo Mafalda Jr. ${ }^{1}$, Soluna Sallés ${ }^{2}$, Teodoro Ramirez ${ }^{2}$, \\ Dolores Cortés ${ }^{2}$, Alberto Garcia ${ }^{2}$, Jesus Mercado ${ }^{2}$ and Manuel Vargas-Yañez ${ }^{2}$ \\ ${ }^{1}$ Instituto de Biologia; Universidade Federal da Bahia; 40210-020; Salvador - BA - Brasil ${ }^{2}$ Centro Oceanográfico \\ de Málaga Fuengirola; Instituto Español de Oceanografía Muelle Pesquero, s/n; 29640; Fuengirola - Málaga - \\ España
}

\begin{abstract}
The annual cycle of marine cladocerans was studied over six years from 1994 to 1999 within the frame of the monitoring Project ECOMALAGA at a nine stations in the NW of the Alboran Sea, with the aim of assessing seasonal patterns and interannual trends in distribution and abundance of marine cladocerans. Seven species (Penilia avirostris, Evadne nordmanni, Evadne spinifera, Pseudoevadne tergestina, Pleopis polyphemoides, Podon leuckarti and Podon intermedius) were detected in the northwest Alboran Sea. Total cladoceran relative abundance varied from 0 to $89 \%$ of the total cladocerans. The abundance of cladocerans was higher in summer-autumn than in winter-spring (7012 - 4711.100 and $743-217.100 m^{-3}$, respectively). The species composition was very different in terms of seasonality. P. polyphemoides, P. leuckarti and P. intermedius appeared mostly during the spring. P. tergestina, E. spinifera and E. nordmanni predominantly occurred during the winter. P. avirostris occurred mostly during the summer and autumn.
\end{abstract}

Key words: Alboran Sea, marine cladocerans, distribution and abundance

\section{INTRODUCTION}

Only eight species of cladocerans have been known to be distributed in the world oceans. Most marine cladocerans are restricted to coastal waters, where they make up a significant part of the zooplanktonic community at given periods. This confers on these animals a major trophodynamic role, as they can be an important food item for carnivorous zooplankton, as well as pelagic fish and their larvae (Cheng and Chao, 1982). Despite their high densities, marine cladocerans may disappear from the plankton during certain seasons of the year, which in temperate regions is generally in winter (Onbé, 1974, 1978, 1985; Ramirez and Perez Seijas, 1985).

In temperate, subtropical and tropical seas, they comprise significant portions of the local zooplankton community, usually represented by Penilia avirostris and Pseudoevadne tergestina. However, other species such as Evadne nordmanni and Podon leuckarti, if present, appear at low densities only in low temperature months, and are regarded as cold-water species (Onbé et al. 1996).

*Author for correspondence: chsampaio@ig.com.br 
For instance, in temperate and tropical ecosystems, marine cladocerans are the dominant zooplankters of summer communities in coastal waters, when the water stability increases and prokaryotic picoplankton comprise much of the primary producer's biomass (Onbé 1985; Calbet et al. 2001). In the coastal NW Mediterranean, during summer the cladoceran Penilia avirostris shares its dominance on the zooplanktonic community (Calbet et al. 2001). These groups of organisms are cosmopolitan and occur commonly in nearshore (Onbé 1985; Wong et al. 1992; Calbet et al. 2001).

Despite their high seasonal abundance and role in marine systems, cladocerans have been little studied compared to copepods, and the reasons for their explosive community growth are still unknown. Therefore, the present study characterized the cladoceran community of the Northwest Alboran Sea (Western Mediterranean) and evaluated its distribution and abundance in order to assess the seasonal cycles and detect possible temporal trends.

\section{Study Area}

The study area was delimited to the north by the coast malagueña; to the west by Cabo Pino $\left(4^{\circ} 44^{\prime}\right.$ $53 \mathrm{~W})$, and to the east by the Caleta de Vélez $\left(4^{\circ} 03^{\prime}\right.$ $90 \mathrm{~W})$. The northwestern sector of the Alboran Sea is a favourable reproductive habitat, as well as a nursery ground (García et al., 1988; Rodríguez, 1990). The Atlantic jet which penetrates through the Strait of Gibraltar (Parrilla and Kinder, 1987) produces a system of two anticyclonic gyres which occupy the central part of the eastern and western basins of the Alboran Sea. According to Rubín et al. (1999), the upwelling of deeper Mediterranean waters enriched in inorganic nutrients is induced by several mechanisms (Parrilla and Kinder, 1987; Sharhan et al., 2000). This enrichment mechanism favours the presence of cores of high phytoplankton and zooplankton abundance (Cortés et al., 1985; García-Górriz and Carr, 2001; Minas et al., 1991; Ruíz et al., 2001; Rodríguez et al., 1982, 1997). Although this hydrological pattern is maintained during the entire annual cycle, seasonal changes in the water column stratification and intensity of the Atlantic water inflow have been described (García-Lafuente et al., 2000), thereby affecting the strength of upwelling off the Malaga coast (Ramírez et al.,2005). Accordingly, annual peaks of nutrient concentration and chlorophyll-a tend to be detected in spring (Mercado et al., 2006;
Ramírez et al., 2006). Souza et al. (2005) have described a seasonal succession pattern for the zooplankton communities.

\section{MATERIALS AND METHODS}

The samples for plankton were collected quarterly data from 1994 to 1999 in nine stations located in three transect (P, Cabo Pino; M, Malaga and V, Caleta de Vélez), whose depths varied between 25 and $500 \mathrm{~m}$. The stations P1, M1 and V1 were located in the coastal area; P2, M2 and V2 were situated in shelf break and P3, M3 and V3 were located in oceanic area (Fig. 1). The surveys were carried out in January-February (winter period), March-April (spring period), June-July (summer period) and October-November (autumn period) on board the RV 'Odón de Buen'. The collections of the 216 samples was done with a Bongo $40 \mathrm{~cm}$ of mouth size ( $200 \mu \mathrm{m}$ mesh) up to $100 \mathrm{~m}$ depth. The nets were equipped with two flowmeters independent to estimate the water volume filtered. Marine cladocerans were identified and counted on a Bogorov plate using a stereoscopic microscope Leica MZ8 from an aliquot obtained by a Folson sub-sampler, the standard densities of the species were expressed as the number per 100 $\mathrm{m}^{-3}$ of filtered water for each collection. The vertical profiles of temperature and salinity were obtained with a Seabird 25 CTD at ach station during all the surveys.

\section{Data analysis}

Correspondence Analysis (CA), which represented the species and samples as occurring in a postulated environmental space, or ordination space, was used to explore the seasonal trends of the species of marine cladocerans. The raw abundance data matrix was transformed logarithmically according to $\log (n i, j+1)$, where ni was the abundance of the ith group in the jth sample. The correspondence Analysis (CA) assumes that species have unimodal species response curves. A species is located in that location of space where it is most abundant. Correspondence Analysis was employed for this study using the CANOCO program.

A MRPP (Multi-response Permutation Procedures) analysis was utilised in order to prove the existence of significant differences in the composition of marine cladocerans between the study periods. 


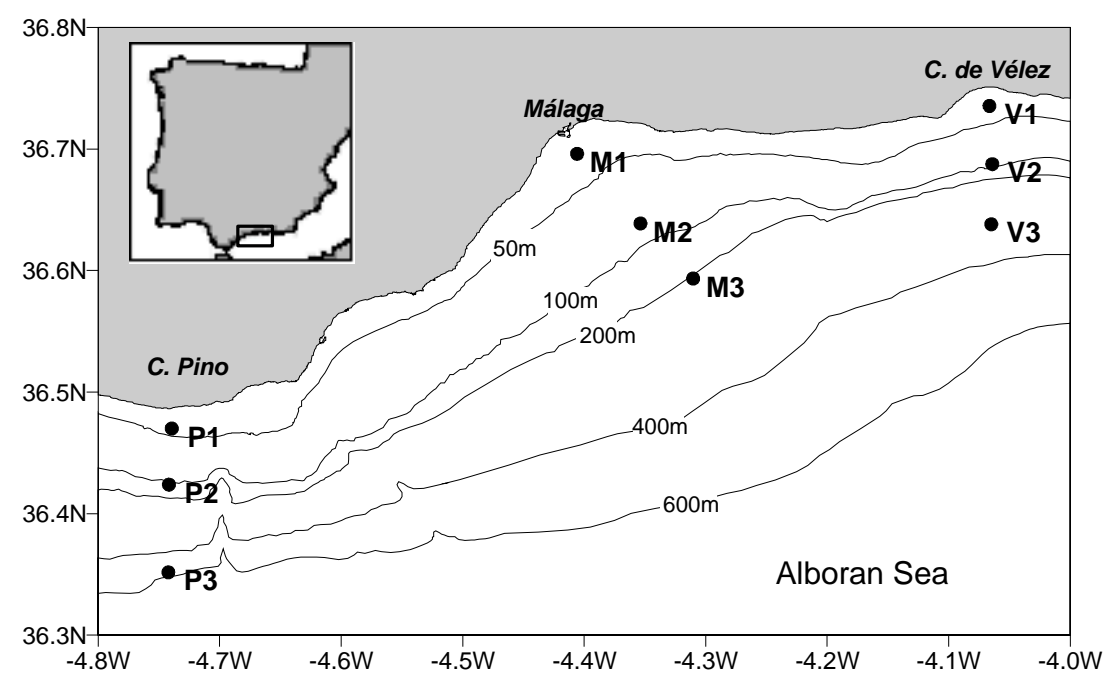

Figure 1 - Sampling sites and topography in the NW of the Alboran Sea, Spain.

\section{RESULTS}

\section{Hydrographic condition}

The extreme values of temperature were 14.2 and $21.1^{\circ} \mathrm{C}$. The temperature showed an annual variation, with maximums in summer-autumn and minimums in winter and spring (Fig. 2). The data of salinity oscillated between 36.5 and 37.5. Salinity variations also followed a seasonal pattern, with values more elevated in spring and lower in autumn (Fig. 2). During the period of spring-summer was observed stratification in the water column with the termoclina located between 25 and $50 \mathrm{~m}$. However, during the autumn-winter, the water column was mixed. The zones of outcrops were located in the bay of Malaga and radial of Cabo Pino. These events were associated to winds of the west, which pushed the water of the coast towards open sea, giving rise to an inequality in the level of the sea that was compensated with the deep water contribution, cold and rich in nutrients. The Atlantic Water (AW), which penetrates by the Straits of Gibraltar, extends by the Alborán Sea upon the Mediterranean Intermediate Water (MIW). The greater space uniformity of temperature and salinity occurred in the autumn when there was a greater Atlantic water entrance, whereas in spring, the Atlantic water was modified by mixture with Mediterranean water (Mafalda Jr. and Rubín, 2006).
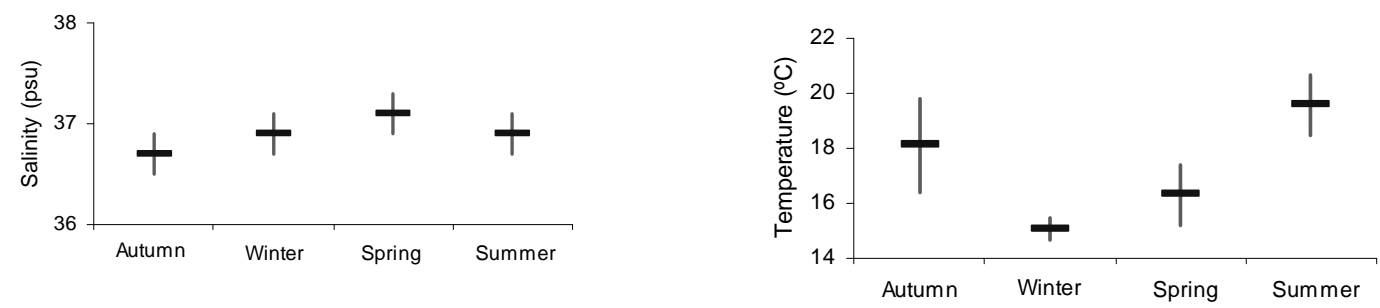

Figure 2 - Mean (m) and standard deviation (sd) of temperature $(10 \mathrm{~m})$ and salinity $(10 \mathrm{~m})$, between 1994 - 2000.

\section{Cladoceran occurrence and composition}

Seven cladoceran species were identified: Penilia avirostris Dana, 1849, Pseudoevadne tergestina Claus, 1877, Evadne spinifera P. E. Müller, 1867, Evadne nordmanni Lovén, 1836, Pleopis polyphemoides Leuckart, 1859, Podon leuckartii
(G. O. Sars, 1862), Podon intermedius Lilljeborg, 1853. The relative abundance of cladoceran species varied from 0 to $89 \%$ of the total cladocerans. The most abundant species was Penilia avirostris, varying from 9 to $89 \%$ of the total cladocerans. The higher abundance was 
observed during the summer and autumn, while winter was lowest abundance. Another abundant species was Evadne nordmanni which varied from 0 to $59 \%$. It was most abundant in winter. Evadne spinifera was more abundant in winter and spring and varied from 4 to 24\%. Pseudoevadne tergestina abundance varied from 1 to $6 \%$ and showed higher abundance in winter. Pleopis polyphemoides varied 0 to $15 \%$, Podon leuckarti and Podon intermedius varied 0 to $8 \%$ with higher abundance observed during spring.

The most frequent species in all the studied samples was Penilia avirostris with $100 \%$ during summer and $98 \%$ during autumn, followed by Evadne spinifera $(83 \%$ during summer and $87 \%$ during autumn) and Pseudoevadne tergestina (65\% during summer and 69\% during autumn). Pleopis polyphemoides, Podon leuckarti and Podon intermedius occurred most frequently during spring and summer (52 and 74\%; 24 and $35 \% ; 31$ and $22 \%$ respectively).
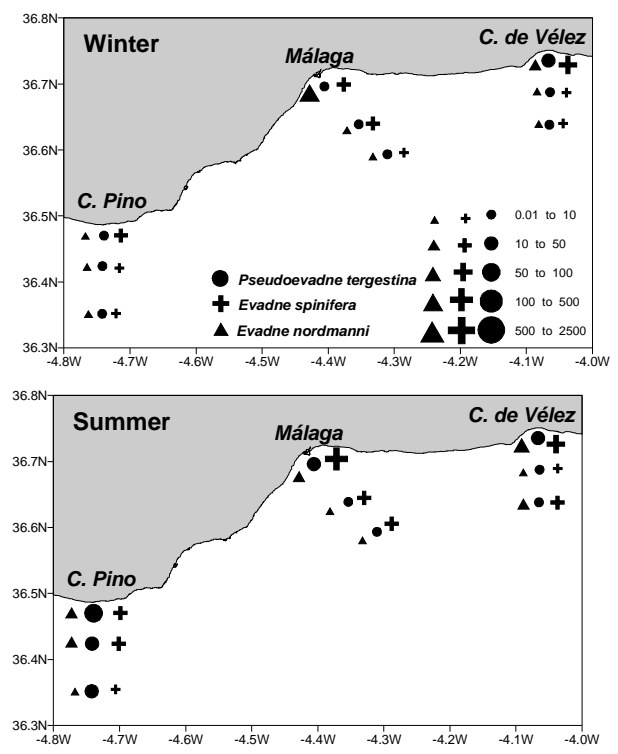

The MRPP test showed differences in the composition of marine cladocerans between the study periods $(\mathrm{p}=0.0067)$

\section{Spatial and temporal distribution of species}

All the species of cladocerans were collected in all seasons of the year occurring in coastal, shelf break and oceanic areas of the Alboran sea. Penilia avirostris showed large distribution occurring in all the regions. The maximum density was observed during the summer and autumn in coastal area in all the transects (Fig. 5). Pseudoevadne tergestina, E. spinifera, E. nordmanni, Pleopis polyphemoides and Podon leuckarti too showed the maximum density during the summer and autumn in the coastal area but with less density than $P$. avirostris. Podon intermedius was found predominantly during the spring in coastal stations in transect V (Fig. 3 and 4).
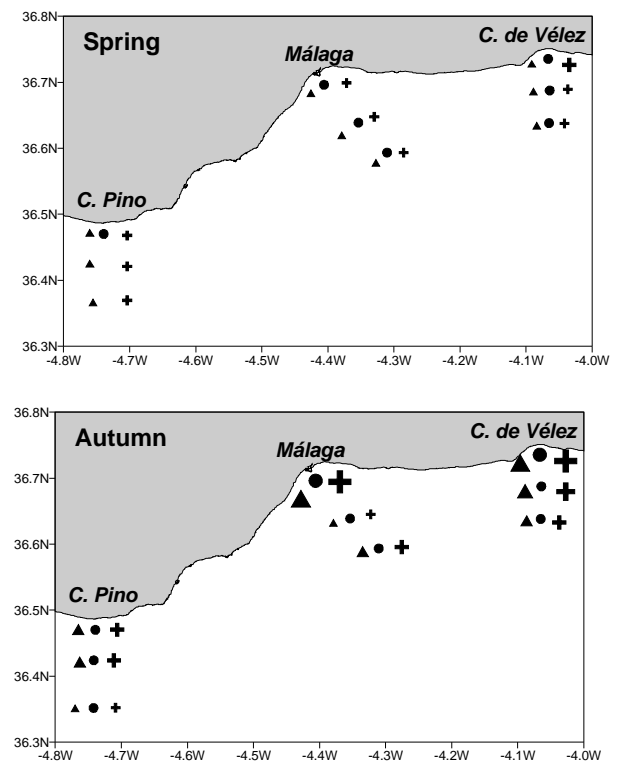

Figure 3 - Temporal and spatial distribution of Pseudoevadne tergestina, Evadne spinifera, Evadne nordmanni $100 \mathrm{~m}^{-3}$ (densities), in the Northwest Alboran Sea from 1994 to 1999.

\section{Seasonal trends of species}

The correspondence analyses showed the relationships of cladocerans species and periods in the Northwest Alboran Sea. Axes represent degree of relationship obtained from the analyses, such that proximity and similar location indicate closeness. The eigenvalues for the first two axes were 0.53 and 0.16 , respectively. The sum of all the eigenvalues of $\mathrm{CA}$ was 0.87 . The first four ordination axes of CA cumulatively explained $96 \%$ of species variance with the first two axes explaining about $79.4 \%$ of the variance. Axis-1 separated the winter stations from the spring and autumn stations. Axis- 2 further differentiated the autumn stations and spring stations, denoting seasonal changes in the abundance of marine cladocerans (Fig. 6). 

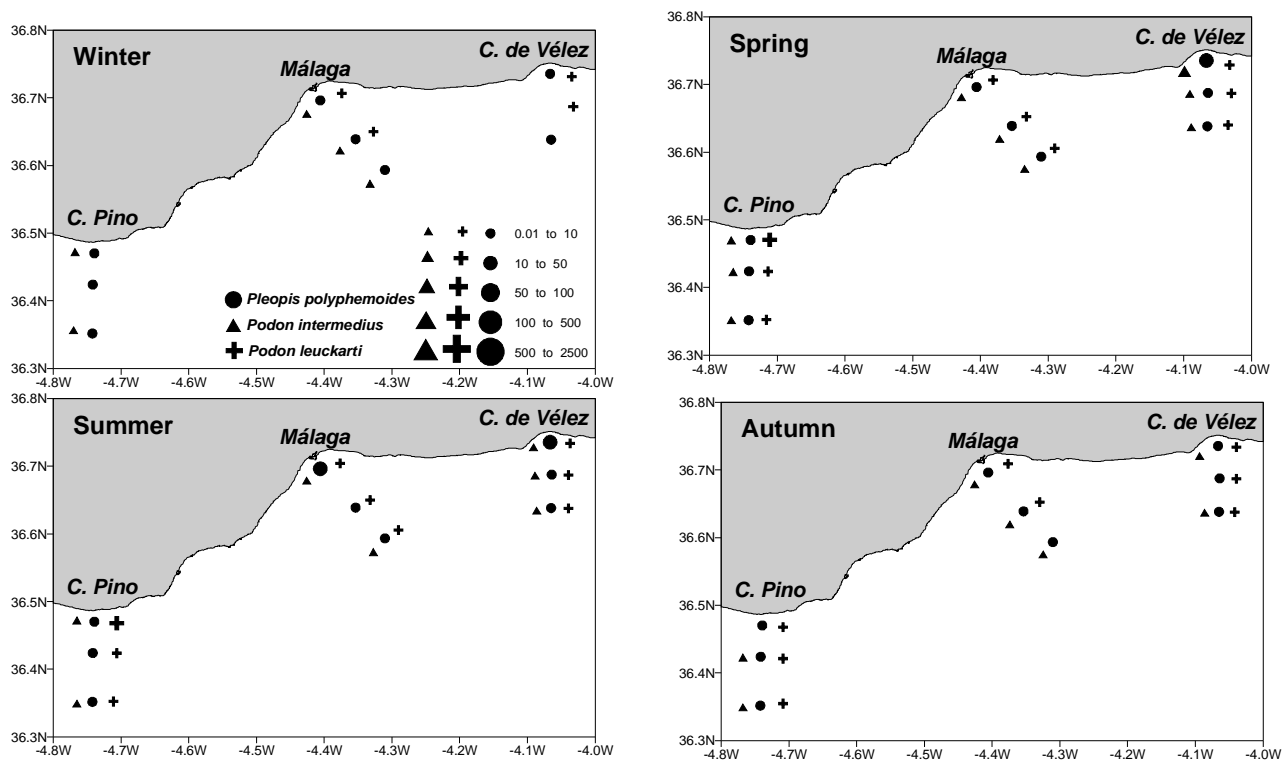

Figure 4 - Temporal and spatial distribution of Pleopis polyphemoides, Podon leuckarti and Podon intermedius. $100 \mathrm{~m}^{-3}$ (densities), in the Northwest Alboran Sea from 1994 to 1999.
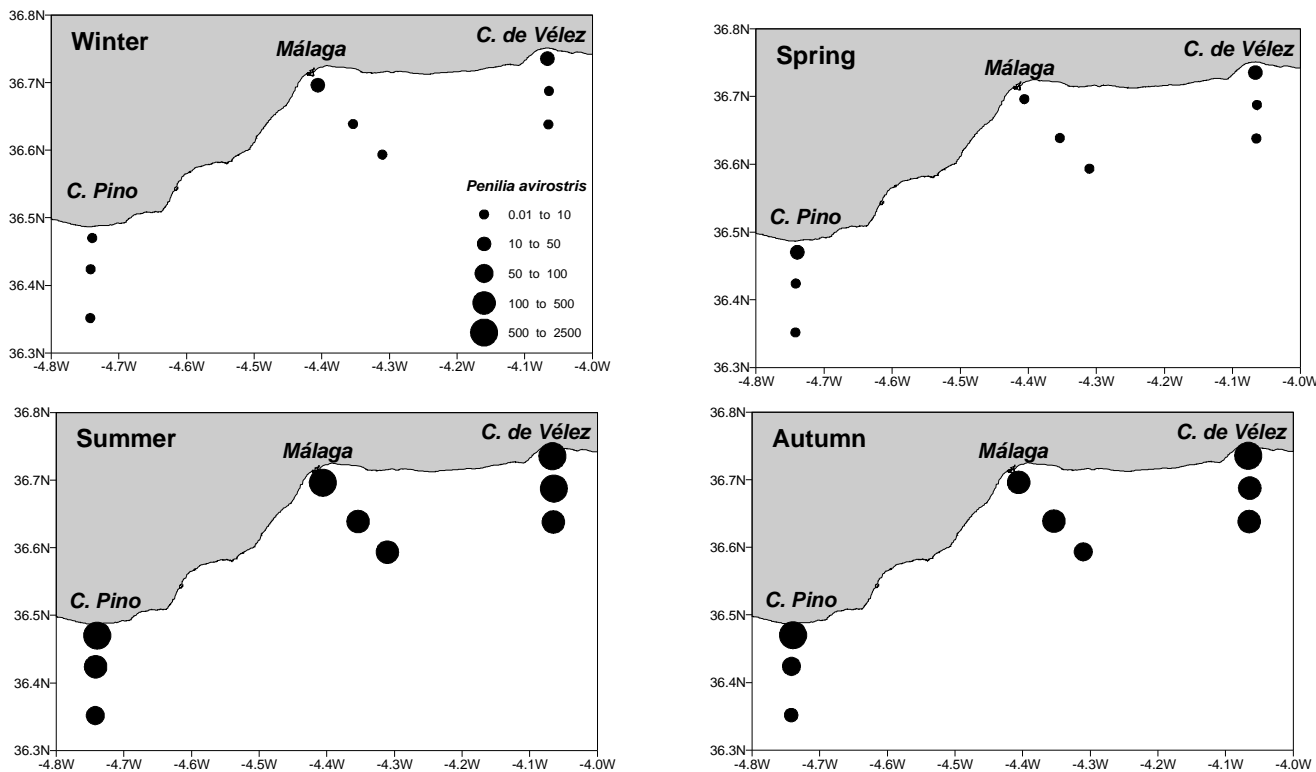

Figure 5 - Temporal and spatial distribution of Penilia avirostris.100 $\mathrm{m}^{-3}$ (densities), in the Northwest Alboran Sea from 1994 to 1999.

The plot of CA sample and species scores illustrates their dispersion pattern within the first two dimensions of the CA ordination (Fig. 6). Figure 6, showed that, the species composition was very different in terms of seasonality. Pleopis polyphemoides, Podon leuckarti and Podon intermedius were positively correlated with the first CA axes and negatively with the second, appeared mostly during the spring stations. Pseudoevadne tergestina and Evadne spinifera were negatively correlated with the first CA axes and positively with the second, predominantly occurred during the winter stations. Evadne nordmanni was positively correlated with the first 
and second CA axes, predominantly occurred during the winter stations. Penilia avirostris was negatively correlated with the first and second CA axes, occurred mostly during the summer and autumn stations.

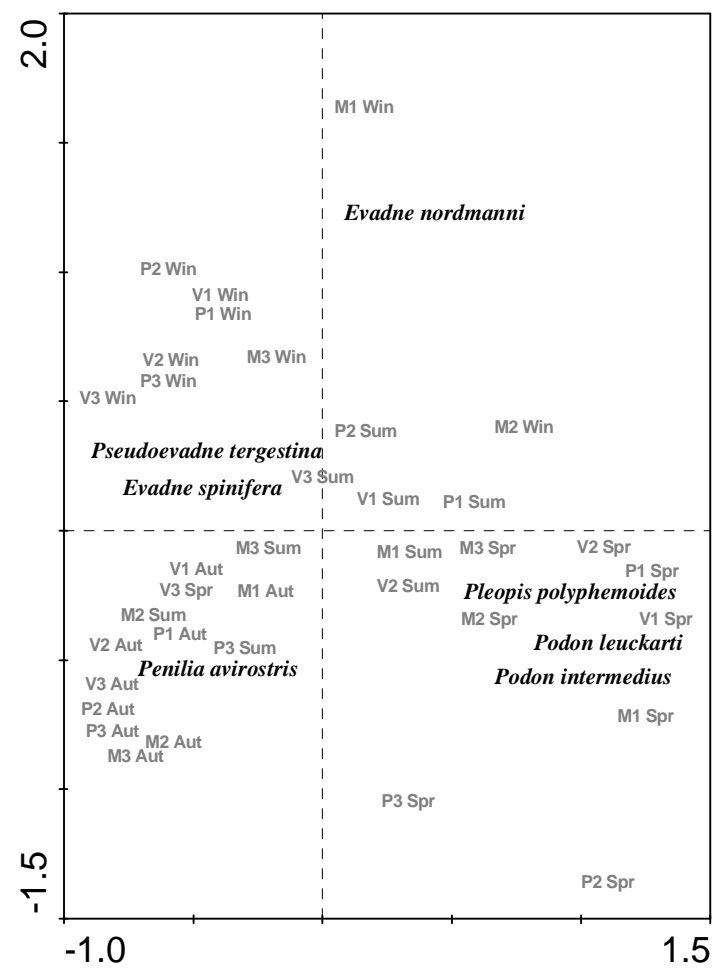

Figure 6 - Biplot of the species scores and samples in the first two correspondence analysis dimensions. Win (winter), Sum (summer), Aut (autumn), Spr (spring).

\section{DISCUSSION}

The present study revealed seven species of cladocerans, Penilia avirostris, Pseudoevadne tergestina, Evadne spinifera, Evadne nordmanni, Pleopis polyphemoides, Podon leuckarti and Podon intermedius. The species of cladocerans found in the study area was typical of marine environments (Coelho-Botelho et al., 1999; Lopes, 1996; Montú, 1980; Nogueira et al., 1999; Valentin and Marazzo, 2003; Marazzo and Valentin 2004). Penilia avirostris, Pseudoevadne tergestina and E. spinifera are recognised as typical from the warm water. Thus, they are frequently associated (Della Croce and Venugopal, 1972; Onbé, 1974; Ramirez, 1981). P. avirostris is a cosmopolitan species. It is typical of coastal environment and shows high eurihalinity. A few results are found in literature about E.spinifera; this may be due to its rare occurrence and lower abundance in the neritic waters, when compared to other cladoceran species. E. spinifera is more abundant in high-temperature oceanic waters, and has been classified as a typical thermophile and stenohaline species (Gieskes, 1971). Evadne nordmanni has been reported to occur in the oceanic waters in the North Atlantic and the North Sea (Gieskes, 1970, 1971a), the Indian Ocean (Della Croce and Venugopal, 1972) and the northwestern Pacific (Kim, 1989). They usually about in the neritic regions (Onbé 1974; Kim et al., 1989). P. leuckarti is also known to be distributed in neritic waters (Gieskes 1970, 1971b; Onbé and Ikeda 1995).

High abundance of cladocerans recorded in the present study occurred in the coastal region. Penilia avirostris abundance peaks were related during the summer and autumn, these species was shown to prefer less saline and warmer waters which prevailed there at that time. According to Onbé and Ikeda (1995), among the seven species of marine cladocerans occurring in Toyama Bay (southern Japan Sea), Penilia avirostris was one of the important members of the plankton in summer. This species is an important component of the zooplankton in the coastal waters like in the coast off Northwest Alboran Sea in certain periods of 
the year, along with other species such as Pseudoevadne tergestina and Pleopis polyphemoides and is an important contributor to secondary production. However, Penilia avirostris may disappear from the plankton at certain periods. In Guanabara Bay, Marazzo and Valentin (2001) observed that Penilia avirostris reached its maximum density during the autumn and disappeared in the winter and spring.

The composition, abundance and spatial distribution of the cladocerans in the Northwest Alboran Sea have been related to the seasonal variation pattern in the hydrology.

The most conspicuous temporal variation pattern for the cladocerans abundance was characterised by higher abundances in summer and lower in spring. This seasonal pattern matches the one described for the zooplankton biomass by García and Camiñas (1985) in the northwestern Alboran Sea, although it contrasted with the seasonal variations obtained for other locations at the western basin of the Mediterranean Sea, where lower biomasses were usually found in the summer, and higher values were obtained from April to June (Sabatés et al., 1989; Fernández de Puelles, 1990; Champalbert, 1996).

The composition and abundance of the zooplankton communities can be influenced by several physical, chemical and biological factors (Neves et al., 2003). Temperature can cause changes in the community composition as well as density. All of them are the important factors determining seasonal distribution of marine cladocerans (Marazzo and Valentin, 2004). Other factors such as salinity, dissolved oxygen, tidal currents, can also affect the occurrence and distribution of cladocerans (Valentin and Marazzo, 2003; Marazzo and Valentin, 2004).

Possibly temperature and salinity were directly or indirectly responsible for the seasonal changes in the populations of cladocerans species. An apparent consensus seems to prevail among the researchers that temperature variations are conditioning factors in reproductive changes found in the marine cladocerans in temperate regions. This is because these organisms are very evenly distributed from spring to autumn. But with the start of winter, depressive features are in evidence and, shortly thereafter, the species disappear from the plankton. Undoubtedly, determining the factors depressing for marine cladocerans is of extreme relevance, as these organisms display significant reproductive changes in response to a number of environmental conditions and, thus, these changes may become effective ecological indicators, as has been proposed by Gieskes (1971). Yet, the rare occurrence of some species can be due to the oblique hauls (Pseudoevadne tergestina and Evadne spinifera show preference to surface zone) and/or due to the mesh size chosen $(100 \mu \mathrm{m}$ is recommended instead of $200 \mu \mathrm{m}$ ), which can be too coarse to retain the small species (Onbé, 1999).

In conclusion, the results of this study demonstrated that there were seasonal changes in the distribution and abundance of marine cladocerans of the northwest Alboran Sea in response of hydrological changes.

\section{ACKNOWLEDGEMENTS}

The monitoring program ECOMÁLAGA could not have been carried out without the technical assistance of many people belonging to the Instituto Español de Oceanografía (Ministerio Español de Educación y Ciencia, MEC) who have collaborated in the surveys and analysis samples.

\section{REFERENCES}

Bartual A.; Reul A.; Rodríguez V. (2001), Surface distribution of chlorophyll, particles and gelbstoff in the Atlantic jet of the Alborán Sea: from submesoscale to subinertial scales of variability. $J$. of Mar. Sys., 29, 277-292.

Bakun A. (1996), Patterns in the Ocean: Ocean Processes and Marine Population Dynamics. San Diego, CA: University of California Sea Grant, in cooperation with Centro de Investigaciones Biológicas del Noroeste, La Paz, Baja California Sur, México, 323pp.

Calbet A.; Garrido S.; Saiz E.; Alcaraz M.; Duarte M. (2001), Annual zooplankton succession in coastal NW Mediterranean waters: the importance of the smaller size fractions. J. Plank. Res., 23, 319-331.

Cortés D.R.; Gil J.; Garcia A. (1985), General distribution of chlorophyll, temperature and salinity in the north-western sector of Alboran Sea. In: Communication from the XXIX Congres-Assemblee pleniere CIESM. Lucerne, pp. 11-19.

Cheng, C. and Chao, W. C. (1982), Studies on the marine Cladocera of China II. Distribution. Acta Oceanol. Sinica. 4, 731-742.

García A.; Cortés D.; Ramírez T. (1998), Daily larval growth and DNA and RNA content of the Northwest Mediterranean anchovy Engraulis encrasicolus and 
their relation to the environment. Mar. Ecol. Pro. Ser., 166, 237-245.

García-Górriz E. and Carr M. E. (2001), Physical control of phytoplankton distributions in the Alboran Sea: a numerical and satellite approach. J. of Geophy. Res., 106, 16795-16805.

García-Lafuente J.; Vargas J. M.; Candela J.; Bascheck B.; Plaza F.; Sarchan T. (2000)., The tide at the eastern section of the strait of Gibraltar. J. of Geophy. Res., 105 (C6), 14197-14213.

Mafalda P. Jr. and Rubín J. P. (2006), Interannual Variation of Larval Fish Assemblages in the Gulf of Cádiz (SW Iberian Peninsula) in Relation to Summer Oceanographic Conditions. Braz. Arch. of Biol. and Tech., 49 (2), 287-296.

Mercado J. M.; Ramírez T.; Cortés D.; Sebastián M.; Reul A.; Batista B. (2006), Diurnal changes in the bio-optical properties of the phytoplankton in the Alborán Sea (Mediterranean Sea). Est. Coa. and Shelf Sci., 69, 459-470.

Minas H. J.; Coste B.; LeCorre P.; Minas M.; Raimbault P. (1991), Biological and geochemical signatures associated with the water circulation through the Strait of Gibraltar and in western Alboran Sea. J. of Geophy. Res., 96, 8755-8771.

Onbé T. (1974), Studies on the ecology of marine cladocerans. J. Fac. Fish. Anim. Husb. Hiroshima Univ., 13, 83-179.

Onbé T. (1978), Life cycle of marine cladocerans. Bull. Plankton Soc, 25, 41-54.

Onbé T. (1985), Seasonal fluctuations in the abundance of populations of marine cladocerans and their resting eggs in the Inland Sea of Japan. Mar. Biol., 87, 83-88.

Onbé T.; Tanimura A.; Fukuchi M.; Hattori H.; Sasaki H.; Matsuda O. (1996), distribution of marine cladocerans in the northern Bering sea and the Chukchi sea. Proc. NIPR Symp. Polar Biol., 9, 141152.

Parrilla G. and Kinder T. H. (1987), Oceanografía física del Mar de Alborán. Bol. del Ins. Espanol de Ocean., 4 (1), 133-165.

Ramirez F. C. and Perez Seijas G. M. (1985), New data on the ecological distribution of cladocerans and first local observations on reproduction of Evadne nordmanni and Podon intermedius (Crustacea, Cladocera) in Argentine Sea waters, Physis A, 43, 131-143.

Ramírez T.; Cortés D.; Mercado J. M.; Vargas-Yánez M.; Sebastián M.; Liger E. (2005), Seasonal dynamics of inorganic nutrients and phytoplankton biomass in the NW Alboran Sea. Est.Co. and Shelf Sci., 65, 654-670.

Ramírez T.; Liger E.; Cortés D.; Mercado J. M.; Vargas M.; Sebastián M. (2006), Electron transport system activity in an upwelling area of the NW Alborán Sea. J. of Plankton Res., 65, 654-670.
Rodríguez J. M. (1990), Contribution to the icthyoplankton study in the Alboran Sea. Bol. del Inst. Espanol de Ocean., 6, 1-19.

Rodríguez J.; García A.; Rodríguez V. (1982), Zooplanktonic communities of the divergence zone in the northwestern Alboran Sea. Publi. Staz. Zoo. di Napoli I.

Rodríguez V.; Blanco J. M.; Jiménez-Gómez F.; Rodríguez J.; Echevarría F.; Guerrero F. (1997), Distribución espacial de algunos estimadores de biomasa fitoplanctónica y material orgánico particulado en el mar de Alborán, en condiciones de estratificación térmica (julio de 1993). Mar. Eco., 2, 133-144.

Rubín J. P.; Cano N.; Prieto L.; García M. C.; Ruíz J.; Echevarría A.; Corzo A.; Gálvez J. A.; Lozano F.; Alonso-Santos J. C.; Escánez J.; Juárez A.; Zabala L.; Hernández F.; García Lafuente J.; Vargas M. (1999), La estructura del ecosistema pelágico en relación con las condiciones oceanográficas y topográficas en el golfo de Cádiz, estrecho de Gibraltar y mar de Alborán (sector noroeste), en julio de 1995. Info. Téc. del Inst. Espanol de Ocean., 175, 1-73.

Ruíz J.; Echevarría F.; Font J.; Ruíz S.; García E.; Blanco J. M.; Jiménez-Gómez F.; Prieto L.; González-Alaminos A.; García; C. M.; Cipollini P.; Snaith H.; Bartual A.; Reul A.; Rodríguez V. (2001), Surface distribution of chlorophyll, particles and gelbstoff in the Atlantic jet of the Alborán Sea: from submesoscale to subinertial scales of variability. J. of Mar. Sys., 29, 277-292.

Sabatés A.; Gil J. M.; Pagés F. (1989), Relationship between zooplankton distribution, geographic characteristics and hydrographic patterns off the Catalan coast (Western Mediterranean). Mar. Bio., 3, 153-159.

Sharhan T.; García-Lafuente J.; Vargas M.; Vargas J. M.; Plaza P. (2000), Upwelling mechanisms in the northwestern Alborán Sea. Jour. of Mar. Sys., 23, 317-331.

Souza C.; Mafalda P.; Salles S.; Ramírez T.; Cortés D.; García A.; Mercado J.; Vargas-Yánez M. (2005), Tendencias estaciónales y espaciales en la comunidad mesozoplnactónica en una serie temporal plurianual en el noroeste del Mar de Alborán, Espana. Rev. Bio. Mar. y Ocean., 40 (1), 45-54.

Valentin J. L. and Marazzo A. (2003), Modeling the population dynamics of Penilia avirostris (Branchiopoda, Ctenopoda) in a tropical bay. Acta Oecol., 24, 369-376.

Wong C. K.; Chan A. L. C.; Tang K. W. (1992), Natural ingestion rates and grazing of the marine cladoceran Penilia avirostris Dana in Tolo Harbour, Hong Kong. J. Plankton Res., 14, 1757-1765.

Received: July 30, 2009; Revised: January 11, 2010; Accepted: March 03, 2011 